\title{
Acute renal failure and multiple fistulae formation related to an unusual vaginal foreign body
}

\author{
Georgios Christopoulos, ${ }^{1}$ Claudia Munn ${ }^{2}$
}

${ }^{1}$ IVF Unit, Hammersmith Hospital, London, UK

2Department of Gynaecology, Royal Sussex County Hospital, Brighton, UK

\section{Correspondence to} Georgios Christopoulos, geoichristopoulos@yahoo.com
To cite: Christopoulos G, Munn C. BMJ Case Reports

Published online:

3 December 2012

doi:10.1136/bcr-2012

007540

\section{DESCRIPTION}

A 52-year-old patient presented with suprapubic pain, mild vaginal bleeding and continuous urinary incontinence. The patient was nulliparous with a history of cerebral palsy and mild learning difficulties. A bimanual examination revealed a hard and calcified vaginal mass, which appeared to be in direct continuation with her cervix. Investigations revealed leucocytosis (white blood cell count: $26.7 \times 10^{6} / \mathrm{ml}$ ), raised C reactive protein $(69 \mathrm{mg} / \mathrm{l})$, urea $(41.6 \mathrm{mmol} / \mathrm{l})$ and creatinine $(202 \mathrm{mcg} / \mathrm{l})$, hyponatraemia $(120 \mathrm{mmol} / \mathrm{l})$ and hyperkalaemia $(7.5 \mathrm{mmol} / \mathrm{l})$.

Following acute management of the deranged renal function and electrolytes, she underwent CT of her abdomen and pelvis (figure 1). The findings included normal ovaries and a small uterus with a calcified mass in the upper vagina extending to all fornices. A separate calcified mass was identified inside the bladder. She denied the presence of a ring pessary.

The patient underwent total abdominal hysterectomy and bilateral salpingoophorectomy. During the procedure, a completely calcified aerosol cap was identified in the vagina (figure 2). The cap had been placed in the vagina facing downwards. The foreign object had eroded through the bladder wall and had created a vesicovaginal and right ureterovaginal fistula. The patient had a right ureteric reimplantation and correction of the vesicovaginal fistula.

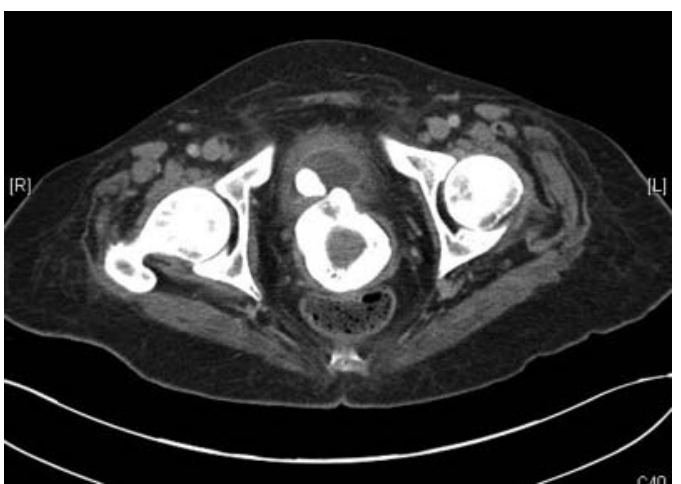

Figure 1 Pelvic CT of patient.

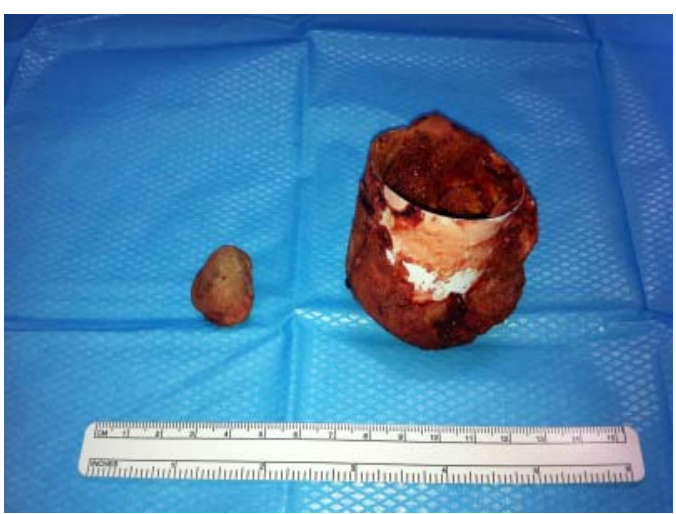

Figure 2 Surgical specimen.

When interviewed further, she denied any history of sexual or physical abuse. She did not wish to disclose why she had inserted the cap.

Vesicovaginal fistulae secondary to foreign bodies have been reported previously. ${ }^{1}$ The images highlight the diagnostic challenge we faced because of incomplete history and significant morbidity associated with foreign vaginal bodies.

\section{Learning points}

- Vaginal foreign bodies may have significant sequelae, including acute life-threatening renal failure and fistula formation.

- History alone may not always highlight the aetiology of symptoms in these sensitive cases.

Competing interests None.

Patient consent Obtained.

\section{REFERENCE}

1 Puppo A, Naselli A, Centurioni MG. Vesicovaginal fistula caused by a vaginal foreign body in a 72-year-old woman: case report and literature review. Int Urogynecol I Pe/vic Floor Dysfunct 2009;20:1387-9. 
Copyright 2012 BMJ Publishing Group. All rights reserved. For permission to reuse any of this content visit http://group.bmj.com/group/rights-licensing/permissions.

BMJ Case Report Fellows may re-use this article for personal use and teaching without any further permission.

Become a Fellow of BMJ Case Reports today and you can:

- Submit as many cases as you like

- Enjoy fast sympathetic peer review and rapid publication of accepted articles

- Access all the published articles

- Re-use any of the published material for personal use and teaching without further permission

For information on Institutional Fellowships contact consortiasales@bmjgroup.com

Visit casereports.bmj.com for more articles like this and to become a Fellow 